\title{
Rapid increase of the grey seal (Halichoerus grypus) breeding stock at Helgoland
}

\author{
K. Abt $\cdot$ J. Engler
}

Received: 2 May 2008 / Revised: 27 October 2008 / Accepted: 29 October 2008 / Published online: 19 November 2008

(C) Springer-Verlag and AWI 2008

\begin{abstract}
Over the past 25 years, the grey seal (Halichoerus grypus) population in the North Sea increased on average at $5 \%$ per year, while founding a number of new colonies. Based on published data, this note compares recent trends in pup production at nine breeding sites, with focus on the German island of Helgoland. Since 1997, numbers born at Helgoland increased at $35 \%$ per year $(95 \%$ CI: 29-42), reaching an all-time high of 53 in 2007. Yet, this was less than $1 \%$ of all grey seal offspring in the North Sea area. Some other small stocks had similarly high growth rates of $20-50 \%$, which must be explained by immigration from the larger colonies, as sustained autochthonous increase cannot exceed 13\% per year in the species. Further, the Helgoland breeding stock increased significantly faster than the neighbouring colonies at Amrum (13\%) and in the Dutch Wadden Sea (20\%), indicating higher offspring survival and/or higher relative influx of migrants. This is attributed to the fact that at Helgoland newborn seals are safe from floodwater. In the other two sites, in contrast, pups are born on sandbanks and are thus often hit by winterly storm tides, which poses a risk to their survival. Because of the favourable breeding conditions at Helgoland, this new colony is expected to soon become an
\end{abstract}

Communicated by H.-D. Franke.

K. Abt $(\bowtie)$

Wildlife Consulting, Samwerstr. 32,

24118 Kiel, Germany

e-mail:k.f.abt@web.de

J. Engler

Faculty of Geography/Geosciences,

Department of Biogeography,

University of Trier, 54286 Trier, Germany important stronghold of the grey seal in the Dutch-German North Sea area.

Keywords Halichoerus grypus $\cdot$ North Sea $\cdot$ Population dynamics $\cdot$ Pup production $\cdot$ Colonization

\section{Introduction}

Grey seals (Halichoerus grypus) inhabit the temperate North Atlantic and adjoining seas. They spend $80 \%$ of their life in the water (McConnell et al. 1999), but haul out regularly on land or ice for gregarious resting and breeding. Like most members of the related genus Phoca, grey seals have single white-coated pups, which are nursed for the short period of 2-3 weeks (Anderson 1992). Age at first parturition is 4-6 years (Anderson 1992), and natality among mature females is about 95\% (Harrison et al. 2006). Monitoring of grey seals is mostly based on numbers of pups, because these can be counted or estimated quantitatively, while estimating the size of the entire population is more difficult (Coulson and Hickling 1964; Duck and Thompson 2007). In 2006, at least 5,300 grey seal pups were born in the North Sea (Table 1), corresponding to a pre-whelping stock of roughly 20,000 animals. Over the past 25 years, the population has been increasing at an average rate of $5 \%$ per year, with yet no indication of a global density effect (Duck and Mackey 2007). The number of colony sites increased during this time by a factor of 2-3 (Table 1), with new foundings occurring particularly in the southern and southeastern part of the North Sea (Fig. 1). In the second half of the 1990s, grey seals started to breed on the small dune island close to Helgoland (Graner 2000). Based on published data, we compare recent trends in pup production of this and other monitored colonies. These 
Table 1 Recent pup production and trends of grey seal breeding stocks in the North Sea

\begin{tabular}{llrl}
\hline Location & $\begin{array}{l}\text { Breeding } \\
\text { since }\end{array}$ & $\begin{array}{l}\text { Pups in } \\
2006\end{array}$ & $\begin{array}{l}\text { Recent } \\
\text { trend } \\
\text { (\% per year) }\end{array}$ \\
\hline Isle of May (GB) & 1960s & 1,800 & \pm 0 \\
Fast Castle (GB) & Mid 1990s & 700 & 15 \\
Farne Islands (GB) & Unknown & 1,200 & \pm 0 \\
Donna Nook (GB) & Early 1970s & 1,000 & 14 \\
Blakeney Point (GB) & Late 1990s & 230 & 50 \\
Horsey (GB) & Late 1990s & 130 & 25 \\
Dutch Wadden Sea (NL) & Mid 1980s & 200 & 20 \\
Helgoland (D) & Late 1990s & 30 & 35 \\
Amrum (D) & Early 1980s & 25 & 13 \\
\hline
\end{tabular}

Sources of data: Harrison et al. (2006); Duck and Mackey (2007); Härkönen et al. (2007); Hüppop and Hüppop (2007); ICES (2007); Jeß and Gaus (2007)

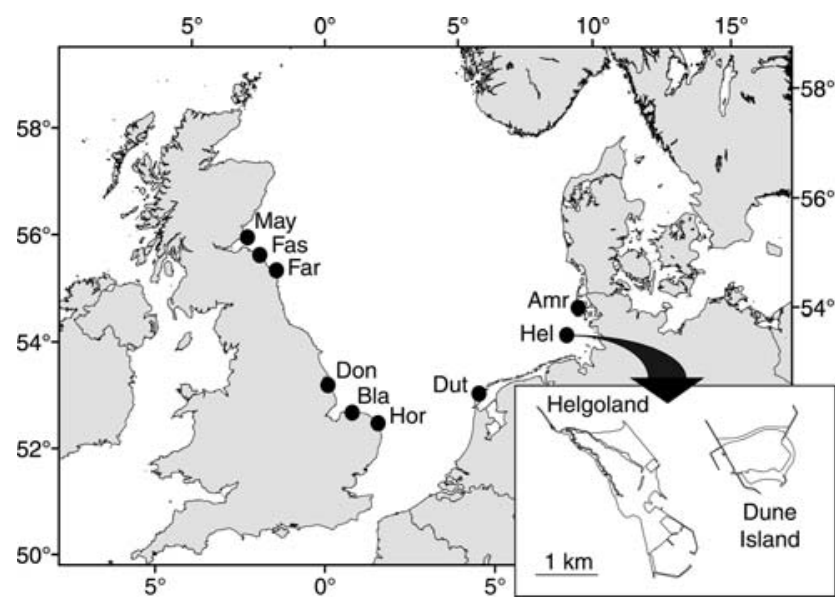

Fig. 1 Grey seal breeding sites in the North Sea and map of Helgoland; May Isle of May, Fas Fast Castle, Far Farne Islands, Don Donna Nook, Bla Blakeney Point, Hor Horsey, Dut Dutch Wadden Sea, Hel Helgoland, Amr Amrum

figures are discussed with respect to the population dynamics, movements, and habitat requirements of the species, aiming to give some outlook on the future delopment of the Helgoland breeding stock.

\section{Study area}

The dune island is located $1 \mathrm{~km}$ east of the main island of Helgoland $\left(54^{\circ} 11^{\prime} \mathrm{N} 7^{\circ} 55^{\prime} \mathrm{E}\right)$ and about $50 \mathrm{~km}$ off the German North Sea coast (Fig. 1). It is $0.6 \mathrm{~km}^{2}$ in size, surrounded by sand and pebble beaches, and is inhabited only from April to October. However, tourists make day trips also in winter, particularly during the grey seal whelping season in December and early January. Most pups are born on the pebble beach on the east side of the island ('Aade'), which provides quick access to higher terrain in case of floodwater. Complete registration of newborns is ensured through almost daily (before 2004: weekly) control of all shores from November through January. To prevent double-counting, dye-marking and flipper-tagging are applied.

\section{Results and discussion}

In the winter of 2007/2008, an all-time high of 53 grey seal pups were recorded at Helgoland (R. Blädel, personal communication). Yet this is one of the smallest monitored breeding stocks in the North Sea (Table 1), contributing less than $1 \%$ to the entire pup production. In the following, years denote the calendar year in which the respective whelping season began. Numbers from 1997 to 2007 follow a loglinear trend (Fig. 2) with a mean growth rate of $35 \%$ per year (95\% CI: 29-42). Mean growth rates of other colonies were in the range of 0-50\% per year during 19972006 (Blakeney Point and Horsey: data available only for 2002-2006), with high values of 20-50\% occurring only in relatively small ones (Table 1). In the large Isle of May and Farne Islands stocks, in contrast, pup production remained about stable. The colonies on the continental coast also increased less rapidly than Helgoland, i.e. Dutch Wadden Sea 20\% and Amrum 13\% per year (Table 1, Fig. 2).

Animal population change in a given area is the result of births, deaths, immigration, and emigration. Of course, there is no explicit knowledge of these quantities for each individual grey seal breeding site in the North Sea, although Harrison et al. (2006) made an attempt to model the dynamics of the four largest colonies. There is, however, strong evidence that sustained autochthonous increase of grey and harbour seals (Phoca vitulina) cannot exceed

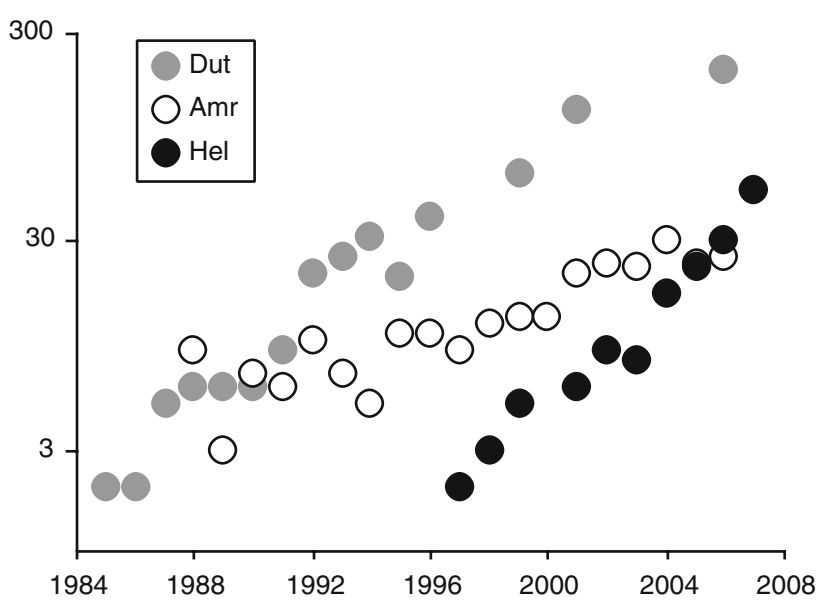

Fig. 2 Annual numbers of recorded grey seal pups (in log scale) at Helgoland $(\mathrm{Hel})$, off Amrum (Amr) and in the Dutch Wadden Sea (Dut) 
$13 \%$ per year (Abt 2002; Bowen et al. 2003). Consequently, all colonies with higher growth rates must have received net influx from other stocks. The distances between all locations in Fig. 1 can be easily covered by grey seals (McConnell et al. 1999).

Despite their mobility, grey seals, like other gregarious animals, do not colonize new terrain too readily (Matthiopoulos et al. 2005). Females in particular show a high degree of site fidelity (Pomeroy et al. 2000). However, conditions that compromise successful breeding, e.g. overcrowding of whelping sites (Coulson and Hickling 1964), may stimulate emigration from the place of birth (Pomeroy et al. 2000; Gaggiotti et al. 2002). This has likely been happening in the Isle of May and Farne Islands colonies, where no more increase was observed in recent years, although the two stocks produced more than $50 \%$ of grey seal offspring in the North Sea. As long as there is no general food limitation, spillover from these colonies should continue, leading to further influx of migrants to Helgoland and some other locations.

We also postulate that in the coming years the majority of grey seals immigrating to the Dutch-German North Sea area will breed at Helgoland, since the dune island provides better conditions than the sandbanks near Amrum and in the Dutch Wadden Sea. The latter are being flooded at storm tides, so that newborns are forced to swim to nearby shores. This can lead to their death due to heat loss (Blume 1996) or because of separation from their mother. Most pups found outside the known breeding sites are therefore taken into rehabilitation centers. From records of these facilities (e.g. Anonymus 2005) it was calculated that at least $40-50 \%$ of grey seals born in the Dutch Wadden Sea are temporarily under human care (K. Abt, unpublished). While this extensive intervention may enable good recruitment, it nevertheless illustrates that breeding conditions for grey seals in that area are poor. This holds even more for Amrum, where a sudden $50 \%$ drop of pup production was observed in 2007 (S. Gaus, personal communication). Apparently, part of the adult females have left this site, as predicted by Abt et al. (2002), because it has been degrading over decades, leading to frequent flooding (Blume 1996). On the Helgoland dune island, in contrast, grey seal pups are safe from floodwater, which naturally ensures good newborn survival. That should make Helgoland a more attractive place to settle for migrant females, as compared to Amrum and the Dutch Wadden Sea. Provided that habitat conditions remain stable or maybe improve through favourable management (Schlawe 2005), the young colony may soon hold a significant part of the Dutch-German grey seal population. Should the recent trend continue, pup production at Helgoland would rise to about 500 by 2017 .

One may ask why grey seals began to rest and breed in this place significantly later than in the neighbouring sites
(Fig. 2). That must be related to the regular presence of humans on the dune island, while the sandbanks are only rarely accessed. Note also that 20 years ago the bank off Amrum was much bigger and provided better conditions than today (Abt et al. 2002). Over the past decades, however, seals in the area have become more tolerant to human disturbance, which may be partly due to the large fraction that were reared and released by the seal stations. Minor timidity of at least some animals and degradation of nearby breeding sites likely gave way to the founding of the Helgoland grey seal colony. Thereupon, the sheer presence of conspecifics may have facilitated the settling of further, partly shyer immigrants (Smith and Peacock 1990).

Acknowledgments We are grateful to the volunteers of the nature conservation society "Jordsand" and the game wardens Rolf Blädel and Dieter Siemens, who collected the field data at Helgoland. We also thank Thomas Schmitt, Tim Coppack, and two anonymous reviewers for helpful comments on earlier versions of the manuscript.

\section{References}

Abt KF (2002) Phänologie und Populationsdynamik des Seehundes (Phoca vitulina) im Wattenmeer: Grundlagen zur Messung von Statusparametern. Ph.D thesis, University of Kiel

Abt KF, Hoyer N, Koch L, Adelung D (2002) The dynamics of grey seals (Halichoerus grypus) off Amrum in the south-eastern North Sea-evidence of an open population. J Sea Res 47:55-67

Anderson SS (1992) Halichoerus grypus (Fabricius, 1791) Kegelrobbe. In: Niethammer J, Krapp F (eds) Handbuch der Säugetiere Europas, vol 6/II. Akademische Verlagsgesellschaft, Wiesbaden, pp 97-115

Anonymus (2005) Zeehondenopvang 2005. Robbenbulletin Pieterburen Winter 2005-1. http://www.zeehondencreche.nl/home/robbenbulletin/RobbenbulletinZomer2006.pdf

Bowen WD, McMillan J, Mohn R (2003) Sustained exponential population growth of grey seals at Sable Island, Nova Scotia. ICES J Mar Sci 60:1265-1274

Blume B (1996) Zur Situation der Kegelrobben im Nationalpark Schleswig-Holsteinisches Wattenmeer-Wurfsaison 1995/96. Seevögel 17:46-55

Coulson JC, Hickling G (1964) The breeding biology of the grey seal, Halichoerus grypus (Fab), on the Farne Islands, Northumberland. J Anim Ecol 33:485-512

Duck CD, Thompson D (2007) The status of grey seals in Britain. NAMMCO Sci Publ 6:69-78

Duck CD, Mackey BL (2007) Grey seal pup production in Britain in 2006. SCOS briefing paper 07/02. University of St Andrews

Gaggiotti OE, Jones F, Lee WM, Amos W, Harwood J, Nichols RA (2002) Patterns of colonization in a metapopulation of grey seals. Nature 416:424-427

Graner F (2000) Kegelrobben im NSG Helgoländer Felssockel. Seevögel 21:13-17

Härkönen T, Brasseur S, Teilmann J, Vincent C, Dietz R, Abt K, Reijnders P (2007) Status of grey seals along mainland Europe from the Southwestern Baltic to France. NAMMCO Sci Publ 6:57-68

Harrison J, Buckland ST, Thomas L, Harris R, Pomeroy PP, Harwood $\mathrm{J}$ (2006) Incorporating movement into models of grey seal population dynamics. J Anim Ecol 75:634-645

Hüppop K, Hüppop O (2007) NSG Lummenfelsen und NSG Helgoländer Felssockel-Übersicht. Seevögel Sonderband, pp 120-128 
ICES (2007) Report of the working group on marine mammal ecology (WGMME), 27-30 March 2007, Vilm, Germany. ICES CM 2007/ACE:03

Jeß A, Gaus S (2007) Bericht zur Wurfsaison der einzigen Kegelrobbenkolonie im Nationalpark Schleswig-Holsteinisches Wattenmeer. Öömrang Ferian, Norddorf

Matthiopoulos J, Harwood J, Thomas L (2005) Metapopulation consequences of site fidelity for colonially breeding mammals and birds. J Anim Ecol 74:716-727

McConnell BJ, Fedak MA, Lovell P, Hammond PS (1999) Movements and foraging areas of grey seals in the North Sea. J Appl Ecol $36: 573-590$
Pomeroy PP, Twiss SD, Duck CD (2000) Expansion of a grey seal (Halichoerus grypus) breeding colony: changes in pupping site use at the Isle of May, Scotland. J Zool Lond 250:1-12

Schlawe C (2005) Die Kegelrobbe (Halichoerus grypus) auf der Helgoländer Düne. Seevögel 26:5-16

Smith AT, Peacock MM (1990) Conspecific attraction and the determination of metapopulation colonization rates. Conserv Biol $4: 320-323$ 